\title{
Article/Artigo
}

\section{Profile of pregnant women and children treated at a reference center for congenital toxoplasmosis in the Northern State of Minas Gerais, Brazil}

\author{
Perfil de mulheres grávidas e crianças atendidas em um centro de referência para toxoplasmose \\ congênita no norte do Estado de Minas Gerais, Brasil
}

Janer Aparecida Silveira Soares ${ }^{1}$, Sílvio Fernando Guimarães Carvalho ${ }^{1}$ and Antônio Prates Caldeira ${ }^{1}$

\begin{abstract}
Introduction: To describe the clinical and epidemiological profile of pregnant women and children treated at a reference outpatient clinic for congenital toxoplasmosis. Methods: Pregnant women potentially exposed to Toxoplasma gondii were observed. Diagnoses were made using serologic tests compatible with acute toxoplasmosis. Children presenting with: Toxoplasma-specific antibodies (IgM or IgA or ascending IgG titers higher than maternal titers in the first 3 months of life) coupled with toxoplasmosis symptoms; intracranial calcifications (by transfontanelar ultrasound or cephalic segment tomography); or retinochoroiditis (by fundoscopy examination) in the first 8 months of life were also included in the study. Results: Fifty-eight mother-child pairs were observed (mean age of the mothers was 22.1 years). Most patients lived in urban areas $(86.2 \%)$ and had attended less than 8 years of school (51.7\%). Diagnosis was made after birth in $19(32.8 \%)$ children. Thirty-four $(58.6 \%)$ women received some type of treatment during pregnancy. Most $(72.4 \%)$ of the children did not present with clinical alterations at birth. The main findings were ophthalmological: 20 (34.5\%) children with retinochoroiditis, 17 (29.3\%) with strabismus, and 7 (12.1\%) with nystagmus. Of the children with retinochoroiditis, 9 presented with subnormal vision. Ten $(32.3 \%)$ out of 31 children presented with intracranial calcifications by cephalic segment congenital toxoplasmosis, and 9 (42.9\%) children presented with delayed psychomotor development. Conclusions: Our results highlight a critical situation. Protocols for follow-up of pregnant women and their children must be created to improve medical care and minimize sequelae.
\end{abstract}

Keywords: Toxoplasmosis. Children. Epidemiology. Transmission.

\section{RESUMO}

Introdução: Descrever o perfil clínico e epidemiológico de gestantes e crianças atendidas em um centro de referência para toxoplasmose congênita. Métodos: Gestantes potencialmente expostas ao Toxoplasma gondii foram estudadas. Os diagnósticos foram feitos através de testes sorológicos compatíveis com toxoplasmose aguda. Crianças que apresentaram anticorpos específicos ( $\operatorname{IgM}$ e IgA ou títulos ascendentes de $\operatorname{IgG}$, superiores aos títulos maternos nos primeiros três meses de vida), juntamente com os sintomas da toxoplasmose, calcificações intracranianas (ultrassom transfontanela ou tomografia do segmento cefálico), ou retinocoroidite (fundoscopia) nos primeiros oito meses de vida, também foram estudadas. Resultados: Foram estudados 58 pares mãe-filho (a média de idade das mães foi de 22,1 anos). A maioria $(86,2 \%)$ das mães residia em áreas urbanas e tinham até 8 anos de escolaridade (51,7\%). O diagnóstico foi feito após o nascimento para 19 (32,8\%) crianças; 34 (58,6\%) mulheres receberam algum tipo de tratamento durante a gravidez. A maioria $(72,4 \%)$ das crianças não apresentou alterações clínicas ao nascimento. Os principais achados foram oftalmológicos: 20 (34,5\%) crianças com retinocoroidite, 17 (29,3\%) com estrabismo e 7 (12,1\%) com nistagmo. Das crianças com retinocoroidite, 9 apresentaram visão subnormal. Calcificações intracranianas estiveram presentes em $10(32,3 \%)$ das 31 crianças que realizaram toxoplasmose congênita de segmento cefálico e $9(42,9 \%)$ crianças apresentaram atraso do desenvolvimento psicomotor. Conclusões: Os resultados mostram uma situação crítica. Protocolos para acompanhamento de gestantes e seus filhos devem ser criados para melhorar o atendimento médico e minimizar sequelas.

Palavras-chaves: Toxoplasmose. Crianças. Epidemiologia. Transmissão.

1. Departamento de Saúde da Mulher e da Criança, Universidade Estadual de Montes Claros, Montes Claros, MG.

Address to: Dr. Antônio Prates Caldeira. Centro de Ciências Biológicas e da Saúde/UNIMONTES. Av. Dr. Rui Braga/Prédio 6, Campus Universitário Prof. Darcy Ribeiro, Vila Mauricéia, 39401-089 Montes Claros, MG, Brasil

Phone: 5538 3229-8000

e-mail: antonio.caldeira@unimontes.br

Received in 19/03/2011

Accepted in 09/09/2011

\section{INTRODUCTION}

Toxoplasmosis is a major public health problem worldwide, especially in its congenital form, where the risk of fetal compromise and sequelae is imminent. A critical aspect of this disease is that most of the afflicted children are asymptomatic at birth, presenting with late complications ${ }^{1-3}$. In addition, the lack of uniformity in the management of pregnant patients can result in severe consequences for newborns, and the lack of standard screening for toxoplasmosis is a significant healthcare challenge. Unfortunately, few countries include toxoplasmosis in the list of diseases investigated during prenatal care, or make toxoplasmosis testing compulsory, with a systematized follow-up for pregnant women and newborns ${ }^{4-6}$.

Several studies have pointed out the difficulties associated with defining the relationships between intrauterine and postnatal treatment advantages. In fact, the vast majority of studies are observational and retrospective, with historical controls, and are not randomized ${ }^{2,7-9}$. Still, current studies agree that shortening the time interval between diagnosis and acute infection during pregnancy and treatment of the mother and newborn during the first year of the newborn's life reduces parasite load and prevents toxoplasmosis sequelae $e^{2,7,8}$.

Knowledge of the profile of pregnant women affected by toxoplasmosis and the actions of health professionals who treat them can be useful for identifying at-risk women and their children. This knowledge is important because early intervention during pregnancy has been shown to prevent the transmission of the parasite and minimize sequelae $^{2,7,8,10}$.

Observational studies, as well as studies conducted in France (where screening for congenital toxoplasmosis is standardized) with historical controls, have shown decreasing levels of acute phase toxoplasmosis infection in pregnant women and a lower incidence of sequelae in the fetus when antibiotics were administered to the mother during pregnancy and to the child during the first year of life ${ }^{8}$. 
In Brazil, few studies have been conducted on congenital toxoplasmosis (CT), and epidemiological knowledge of the disease is required. In addition, knowledge of the diverse clinical manifestations of the disease and the varying degree of involvement of the patients, as well as regional peculiarities, is essential. Research conducted by the Actions and Diagnosis Support Center (NUPAD - Núcleo de Ações e Apoio Diagnóstico) in Minas Gerais, from November 2006 to May 2007, using blood samples on filter paper taken from newborns around the first week of life (the Guthrie test), found an incidence rate of 1 in 589 live births for toxoplasmosis in Northern Minas Gerais (NUPAD: Technical Report sent to the Health Department of Montes Claros, Belo Horizonte, 2007): a far higher incidence rate than that found in other regions of Brazil (approximately 1:1,000 live births), strongly suggesting the need for local studies.

This study aimed to describe the clinical and epidemiological profile and mother-to-child transmission rate of Toxoplasma gondii in a group of pregnant women and newborns treated at an outpatient clinic for infectious diseases in Northern State of Minas Gerais, Brazil.

\section{METHODS}

The study was conducted in Montes Claros, in the Northern State of Minas Gerais (MG). The city is the main regional center and reference point for medical care for a population of over 1.5 million inhabitants. The municipality has approximately 370,000 inhabitants and approximately 6,000 children are born each year. The health assistance network consists of 5 general hospitals, 7 polyclinics, 14 healthcare care facilities, and 59 family health strategy teams.

The study was conducted at the Reference Center for Infectious Diseases (Centro de Referência em Doenças Infecciosas; CERDI), a polyclinic that belongs to the municipal health network that treats patients with infectious diseases. The CERDI has a multidisciplinary team, with infectologists, pediatricians, psychologists, biologists, social assistants, pedagogues, nurses, health assistants, as well as a technical and administrative support team. The target population of this study was composed of children and mothers referred by the maternities and hospitals of the municipality and health departments of neighboring municipalities.

For data collection, standardized medical records were used for the period from January 2002 to May 2010. Therefore, this study is a descriptive, exploratory study with a quantitative approach.

Pregnant women who had possible acute seroconversion were included in this study: diagnoses were based on positive serological tests for Toxoplasma gondii by the identification of Toxoplasmaspecific IgM and or IgA antibodies, or progressively increased IgG titers. Pregnant women with serological tests consistent with the longterm acquisition of immunity prior to the pregnancy were excluded.

Children presenting with congenital toxoplasmosis at birth; intracranial calcifications (by transfontanelar ultrasound or cephalic segment tomography); or retinochoroiditis (by fundoscopy examination) suggestive of toxoplasmosis in the first 8 months of life were included in this study. Children testing positive for Toxoplasma-specific antibodies ( IgM or IgA), or with ascending titers of Toxoplasma-specific IgGs higher than associated maternal titers, in the first three months of life were included as well.

Follow-up losses were defined as children with no follow-up records at the outpatient clinic for at least one year after birth (i.e. children transferred to another service because their parents moved away or those who could not be contacted by active search).

Data collection was carried out by the researchers and all collected variables were entered into the statistical program SPSS ${ }^{\varpi}$ (Statistical Package for the Social Science, version 13.0, for Windows ${ }^{\circledast}$ ) and submitted to specific statistical treatment. Relationships between demographical variables and interventions during pregnancy and the presence of sequelae by the end of the first year of life were estimated using Pearson's Chi-square test or Fisher's exact test, assuming a confidence level of $5 \%(\mathrm{p}<0.05)$.

\section{Ethical considerations}

The protocol for this study was evaluated and approved by the Ethics Committee of the Universidade Estadual de Montes Claros, Brazil.

\section{RESULTS}

A total of 58 mother-child pairs were identified and studied. The main characteristics of the mothers are shown in Table 1 . The study population was predominantly urban $(86.2 \%)$, and from the municipality where the study was conducted. The percentage of teenage mothers was $31 \%(n=18)$, the mean age was 22.1 years and $51.7 \%$ of the pregnant women $(n=30)$ had up to 8 years of school. Only $1(1.7 \%)$ woman reported having received prophylactic counseling regarding Toxoplasma gondii during pregnancy, and most study participants did not know the implications of being acutely infected with the parasite during pregnancy.

For 10 of the women, no serological examinations for Toxoplasma gondii were conducted during pregnancy, whereas the remaining $48(82.8 \%)$ were tested for Toxoplasma gondii in different trimesters. Of these, $41(70.7 \%)$ tested positive for Toxoplasma-specific IgGs, and 2 had antibodies with progressively increasing titers. IgM were measured in 46 (79.3\%) patients, with positive results for $67.2 \%$. IgA dosage was conducted on only 4 pregnant women, 2 (3.4\%) of which were positive. An IgG avidity test was performed on 12 (20.7\%) of the 58 pregnant women, and results were low $(<30 \%)$ in 3 , high $(>60 \%)$ in 7 , and indeterminate in 2 . Amniocentesis was performed on $19(32.8 \%)$ of the pregnant women, and a PCR search for Toxoplasma gondii in the amniotic fluid was positive for 3 (15.8\%) of these.

Most of the children were asymptomatic at birth, and required laboratory, ophthalmological, and image exams in order to define the diagnosis. The main characteristics of the children are shown in Table 2. Some of the children were brought to the clinic months after birth, and were identified by sequelae suggestive of toxoplasmosis, especially sequelae associated with the eyes (e.g. strabismus and retinochoroiditis).

Premature births were reported for only 3 (5.2\%) of the children and low birth weight was reported for 7 (12.1\%). Intercurrences during the neonatal period were reported for $16(27.6 \%)$ of the newborns. Jaundice was the most common alteration in this period, and was observed in 10 (17.2\%) newborns. It should be noted, however, that all cases of jaundice were due to increased indirect bilirubin values, and thus, were not a manifestation of infection by Toxoplasma gondii. Seven (12.1\%) of the children had some degree of respiratory distress, and 3 presented with early neonatal sepsis, while only one presented with cardiac alterations.

All children were assessed by ophthalmologists, and eye injuries were also evaluated by a retina specialist. Examinations were 
TABLE 1- Sociodemographic, clinical, and epidemiological characteristics of mothers treated at the reference center for congenital toxoplasmosis. Montes Claros, State of Minas Gerais, Brazil, 2002-2010.

\begin{tabular}{lcc}
\hline Variables & Number & Percentage \\
\hline Origin & 43 & 74.1 \\
$\quad$ Montes Claros & 15 & 25.9 \\
$\quad$ other municipalities & 50 & \\
\hline Residence & 8 & 86.2 \\
$\quad$ urban zone & & 13.8 \\
$\quad$ rural zone & 18 & 31.0 \\
\hline Age (years) & 32 & 55.2 \\
$\quad<20$ & 2 & 3.4 \\
$20-30$ & 6 & 10.4 \\
$>30$ & & \\
no information & 30 & 51.7 \\
\hline Schooling (years) & 10 & 17.2 \\
$\leq 8$ & 18 & 31.0 \\
8 & &
\end{tabular}

\section{Prenatal serological tests}

$\begin{array}{lll}\text { yes } & 48 & 82.8 \\ \text { no } & 10 & 17.2\end{array}$

\begin{tabular}{lrl}
\hline Serological tests $(\mathbf{n})$ & & \\
none & 10 & 17.2 \\
1 & 9 & 15.5 \\
2 & 31 & 53.4 \\
$\geq 3$ & 8 & 13.8
\end{tabular}

\section{Time of diagnosis*}

$\begin{array}{lrl}1^{\text {st }} \text { trimester } & 10 & 17.2 \\ 2^{\text {nd }} \text { trimester } & 20 & 34.5 \\ 3^{\text {rd }} \text { trimester } & 9 & 15.5 \\ \text { after delivery or in the child } & 19 & 32.8\end{array}$

\begin{tabular}{lrr} 
Treatment during pregnancy & & \\
none & 24 & 41.4 \\
S & 30 & 51.7 \\
P+SD+AF & 2 & 3.4 \\
S-(P+SD+FA) & 2 & 3.4 \\
\hline
\end{tabular}

\section{Length of treatment in months}

$\begin{array}{lrr}\text { none } & 24 & 41.4 \\ \leq 2 \mathrm{~m} & 13 & 22.4 \\ 3-5 \mathrm{~m} & 16 & 27.6 \\ \geq 6 \mathrm{~m} & 5 & 8.6\end{array}$

*diagnosis defined with the finding of positive IgM during pregnancy. ${ }^{* *}$ S: spiramycin; P+SD+FA: pyrimethamine+ sulfadiazine + folinic acid; S-(P+SD+FA): spiramycin alternated with sulfadiazine, pyrimethamine and folinic acid; m: months.

performed on different dates for each patient. For children who presented with lesions at birth, a fundoscopy was performed within 2 days of life, then again at 3 months old, 6 months old and, after 12 months, once every 6 months, after active retinochoroiditis was no longer present. In cases with active retinochoroiditis, examination intervals were every 15 days until complete healing of the lesion. Ocular alterations were observed in 20 (34.5\%) of the children. The most common were retinochoroiditis and strabismus. Of the children with retinochoroiditis, $17 / 20$ presented with macular lesions with some degree of vision impairment, and 9/20 presented
TABLE 2 - Characteristics of newborns exposed to or infected by Toxoplasma gondii, who were treated at the reference center for congenital toxoplasmosis. Montes Claros, State of Minas Gerais, Brazil, 2002-2010.

\begin{tabular}{|c|c|c|}
\hline Characteristics & Number & Percentage \\
\hline \multicolumn{3}{|c|}{ Gestational age (weeks) } \\
\hline$<37$ & 3 & 5.2 \\
\hline$\geq 37$ & 55 & 94.8 \\
\hline \multicolumn{3}{|l|}{ Birth weight (g) } \\
\hline$<2,500$ & 7 & 12.1 \\
\hline $2,500 \mathrm{~g}-4,000$ & 50 & 86.2 \\
\hline$>4,000$ & 1 & 1.7 \\
\hline \multicolumn{3}{|c|}{ Intercurrences in the neonatal period } \\
\hline absent & 42 & 72.4 \\
\hline present & 16 & 27.6 \\
\hline \multicolumn{3}{|c|}{ Alterations in fundoscopy } \\
\hline yes & 20 & 34.5 \\
\hline no & 36 & 62.1 \\
\hline not performed & 2 & 3.4 \\
\hline \multicolumn{3}{|l|}{ Strabismus } \\
\hline yes & 17 & 29.3 \\
\hline no & 41 & 70.7 \\
\hline \multicolumn{3}{|l|}{ Nystagmus } \\
\hline yes & 6 & 10.3 \\
\hline no & 52 & 89.7 \\
\hline \multicolumn{3}{|l|}{ Hepatomegaly } \\
\hline yes & 13 & 22.4 \\
\hline no & 45 & 77.6 \\
\hline \multicolumn{3}{|l|}{ Splenomegaly } \\
\hline yes & 9 & 15.5 \\
\hline no & 49 & 84.5 \\
\hline \multicolumn{3}{|c|}{ Neurologic alterations/PMD delay } \\
\hline yes & 10 & 17.2 \\
\hline no & 48 & 82.8 \\
\hline
\end{tabular}

PMD: psychomotor development.

with subnormal vision observed during follow-up at the outpatient clinic: $90 \%$ of the children with retinochoroiditis had healed lesions at the first examination.

A central nervous system (CNS) investigation was conducted on $14(24.1 \%)$ of the children exposed to Toxoplasma gondii via lumbar puncture, and alterations were found in 9 (15.5\%). Among the most common findings were increased liquor cellularity due to increased mononuclear cell counts, an increase in proteins and a decrease in glucose. Plain skull radiography (AP and lateral) was performed on $49(84.4 \%)$ of the children, and intracranial calcifications were found in 10. Intracranial calcifications (90.9\%) were also the most common alterations observed by cephalic segment computerized tomography, followed by ventricular dilatation (36.4\%) and hydrocephaly (9\%).

Follow-up data on the children revealed that 21 (36.2\%) presented with some type of sequela. The main sequelae identified were: retinochoroiditis, subnormal vision, and psychomotor development delays. Table 3 presents correlations between specific variables and the presence of any sequelae in children at a 1-year follow-up evaluation (at the end of the first year of life). Variables statistically associated with the presence of sequelae in child at the end of the first year of life were: time of maternal diagnosis ( $\leq 3$ months) and lack of specific treatment during pregnancy. 
TABLE 3 - Correlation between clinical and demographic variables of the pregnant women and newborns, and the presence of any sequelae by the end of the first year of life. Montes Claros, State of Minas Gerais, Brazil, 2002-2010.

\begin{tabular}{|c|c|c|c|c|c|c|}
\hline \multirow[b]{2}{*}{ Variables } & \multicolumn{2}{|c|}{ Present sequelae } & \multicolumn{2}{|c|}{ Absent sequelae } & \multirow[b]{2}{*}{ p-value } & \multirow[b]{2}{*}{$\operatorname{PR}(95 \% \mathrm{CI})^{*}$} \\
\hline & $\mathbf{n}$ & $\%$ & $\mathbf{n}$ & $\%$ & & \\
\hline Origin & & & & & 0.505 & $1.45(0.66-3.23)$ \\
\hline Montes Claros & 16 & 76.2 & 17 & 63.0 & & \\
\hline others & 5 & 23.8 & 10 & 37.0 & & \\
\hline Maternal age (years) & & & & & 0.758 & $1.00(0.51-1.97)$ \\
\hline$<20$ & 7 & 33.3 & 9 & 33.3 & & \\
\hline$\geq 20$ & 14 & 66.7 & 18 & 66.7 & & \\
\hline Maternal schooling (years) & & & & & 1.000 & $1.12(0.48-2.8)$ \\
\hline$\leq 8$ & 17 & 81.0 & 21 & 77.8 & & \\
\hline$>8$ & 4 & 19.0 & 6 & 22.2 & & \\
\hline Time of maternal diagnosis (months) & & & & & 0.005 & $3.31(1.31-8.36)$ \\
\hline$\leq 3$ & 17 & 81.0 & 10 & 37.0 & & \\
\hline$>3$ & 4 & 19.0 & 17 & 63.0 & & \\
\hline Treatment during pregnancy & & & & & 0.000 & $6.52(2.21-19.27)$ \\
\hline no & 18 & 85.7 & 5 & 18.5 & & \\
\hline local & 3 & 14.3 & 22 & 81.5 & & \\
\hline Place of residence & & & & & 1.000 & $1.17(0.49-2.79)$ \\
\hline rural & 3 & 14.3 & 3 & 11.1 & & \\
\hline urban & 18 & 85.7 & 24 & 88.9 & & \\
\hline Birth weight (g) & & & & & 0.215 & $1.83(0.99-3.35)$ \\
\hline$<2,500$ & 5 & 23.8 & 2 & 7.4 & & \\
\hline$\geq 2,500$ & 16 & 76.2 & 25 & 92.6 & & \\
\hline Gender & & & & & 0.911 & $0.94(0.48-1.82)$ \\
\hline male & 8 & 38.0 & 11 & 40.7 & & \\
\hline female & 13 & 62.0 & 16 & 59.3 & & \\
\hline
\end{tabular}

\section{DISCUSSION}

The present study should increase our understanding of the clinical, epidemiologic, and transmissibility profile of congenital toxoplasmosis for a group of mothers and their children treated at a reference outpatient clinic in Northern Minas Gerais. Overall, an agreement is evident between our results and the current literature. The merit of the present study is that it provides a general picture of the clinical and laboratorial management of pregnant women potentially exposed to acute infection by Toxoplasma gondii and their children.

Regarding maternal age for acute exposure to Toxoplasma gondii during pregnancy, a mean age of 22.1 years was found, similar to the mean age of 23 years reported by Figueró et al. and 26.3 years reported by Varella et al. ${ }^{11,12}$. Although in disagreement with other studies, maternal schooling greater than 9 years was not found to be a protective factor against the disease $\mathrm{e}^{13,14}$. However, we must emphasize that, in our sample, the evaluation of this protective effect was restricted because this information was missing for 18 women.

A severe flaw was observed as to the lack of counseling about toxoplasmosis, because some studies have shown a $60 \%$ reduction in the acquisition of the acute form of the disease in susceptible women advised during pregnancy ${ }^{13,14}$.

The avidity test was applied only on 12 women, being positive for 3 (i.e. $<30 \%$ ). This result may indicate a delay in starting prenatal care or in delivering results to assistant doctors, as the avidity test was only useful for the diagnosis during the first trimester of pregnancy (up to 16 weeks at the most) according to some authors ${ }^{4,11,15,16}$.

Regarding amniocentesis, a small number of positive PCR results were observed: only 3 out of the 19 pregnant women submitted to the procedure. However, a relevant sensitivity for the test ranging from $62.5 \%$ to $97.4 \%$ has been reported in the literature ${ }^{2,17}$. The low number of positive results from this exam in the sample studied suggests a need for further analyses to establish correlations among the results, the methodology used, and the time they were performed. The literature shows that sensitivity of PCR following amniocentesis varies greatly according to the gestational age at which the infection was acquired, previous use of specific antibiotics, and inadequate storage of the samples ${ }^{17}$.

Although a correlation between the presence of sequelae in the fetus and the lack of treatment during pregnancy has been observed, this result cannot be considered to be definitive, because of difficulties in establishing the active, acute phase of infection during pregnancy. In fact, this has been one of the major dilemmas for studies such as ours, because a routine protocol has not been established, and it is difficult to define the parasitemia phase accurately ${ }^{8,18-22}$. However, this finding is significant in relation to the large percentage of pregnant women with postnatal diagnosis, because of the presence of sequelae in their children. With regard to IgA dosage, it is possible that due to the lack of knowledge and difficulty of having access to this exam, it has been underestimated and not routinely performed by the assistant doctors who have opted instead for only one dosage of positive IgM to guide their management of acutely infected pregnant 
woman $^{2,23} \cdot \operatorname{Ig} \mathrm{A}$ dosage is an important acute phase marker, and has shown good sensitivity in several studies associated with IgM dosage for Toxoplasma gondii, both in pregnancy and for the diagnosis of newborns ${ }^{23,24}$.

In agreement with previous reports in the literature, most (72.4\%) children were asymptomatic at birth: similar data were found by Sáfadi in São Paulo, where 43 children with Toxoplasma gondii were studied, and $88 \%$ were found to have had subclinical infection at birth ${ }^{25}$.

Despite limitations in our knowledge of the precise time of infection (this definition was provided by the maternal exam date), data from this study demonstrate that children diagnosed up to the first trimester of pregnancy presented with more sequelae than those diagnosed after the second and third trimesters $(\mathrm{p}=0.005 ; \mathrm{PR}=3.31$; $95 \% \mathrm{CI}=1.31-8.36)$. These data are consistent with the literature ${ }^{2,24}$.

In this study, it was not possible to verify the impact of treatment on the development of sequelae in children at the end of the first year of life, because some children received treatment for only a few months. The literature reports better results for children who receive treatment for one year than those treated for only one month or not treated at all, with minor eye, hearing, and cognitive sequelae $e^{2,8,19,20,26}$.

Most (95\%) of the children diagnosed with confirmed Toxoplasma gondii also presented with retinochoroiditis in a fundoscopy examination, which is the most common manifestation of the disease. This is similar to the study of Sáfadi et al., wherein 43 children with Toxoplasma gondii were observed and retinochoroiditis was found in $95 \%$ of the cases, most commonly with bilateral commitment, and with macular lesions prevailing over other sites on the retina ${ }^{25}$.

Data reported in the present study have limitations to generalization. The study was carried out on a restricted population, allocated at a reference center. However, we believe that the value of our results should not be underestimated because patient demands occurred randomly, and were derived from several institutions. In fact, there is a lack of studies in our locality, and this study reflects the need for more effective intervention, such as health education for pregnant women and more standardized medical guidelines. Moreover, the number of cases studied is consistent with the literature on this subject.

The results of this study suggest the importance of prophylaxis during pregnancy, and the urgent need for intervention protocols to prevent acute infection during pregnancy, and to minimize sequelae in newborn children.

\section{CONFLICT OF INTEREST}

The authors declare that there is no conflict of interest.

\section{REFERENCES}

1. Dunn D, Wallon M, Peyron F, Petersen E, Peckham C, Gilbert R. Mother-to-Child transmission of toxoplasmosis; risk estimates for clinical counselling. Lancet 1999; 353:1829-1833.

2. Remington JS, McLeod R, Thulliez P, Desmonts G. Toxoplasmosis. In: Remington JS, Klein JO, Wilson CB, Baker CJ, editors. Infectious Diseases of the Fetus and Newborn Infant. $6^{\text {th }}$ ed. Philadelphia: Elsevier Saunders; 2006. p. 947-1091.

3. Holliman RE. Congenital Toxoplasmosis: prevention, screening and treatment. J Hosp Infect 1995; 30 (suppl):179-190.

4. Margonato FB, Silva AMR, Soares DA, Amaral DA, Petris AJ. Toxoplasmose na gestação: diagnóstico, tratamento e importância de protocolo clínico. Rev Bras Saude Mater Infant 2007; 7:381-386.
5. Carellos EVM, Andrade GMQ Aguiar RAL. Avaliação da aplicação do protocolo de triagem pré-natal para Toxoplasmose em Belo horizonte, Minas Gerais, Brasil: estudo transversal em puérperas de duas maternidades. Cad Saude Publica 2008; 24:391-401.

6. Ministério da Saúde. Secretaria de Atenção a Saúde, Departamento de Ações Programáticas Estratégicas. Área Técnica de Saúde da Mulher. Pré-natal e Puerpério: atenção qualificada e humanizada-manual técnico. $3^{\text {rd }}$ ed. Brasília: Ministério da Saúde; 2006.

7. Systematic Review on Congenital Toxoplasmosis study group (SYROCOT), Thiebaut RLS, Chene G, Gilbert R. Effectiveness of prenatal treatment for congenital toxoplasmosis: a meta-analysis of individual patients' data. Lancet 2007; 369:115-122.

8. McLeod R, Kieffer F, Sautter M, Hosten T, Pelloux H. Why prevent, diagnose and treat congenital toxoplasmosis? Mem Inst Oswaldo Cruz 2009; 104:320-344.

9. Gilbert R, Gras L. European Multicentre Study on Congenital Toxoplasmosis Effect of timing and type of treatment on the risk of mother to child transmission of Toxoplasma gondii. BJOG 2003; 110:112-120.

10. Brézin AP, Thulliez P, Couvrer J, Nobre R, McLeod R, Mets MB. Ophthalmic outcomes after prenatal and postnatal treatment of congenital toxoplasmosis. Am J Ophthalmol 2003; 35:779-784.

11. Figueiró-Filho EA, Lopes AHA, Senefonte FRA, Souza Júnior VG, Botelho CA, Figueiredo MS, et al. Toxoplasmose aguda: estudo da frequência, taxa de transmissão vertical e relação entre os testes diagnósticos maternos-fetais em gestantes em estado da Região Centro-Oeste do Brasil. Rev Bras Ginecol Obstet $2005 ; 27: 442-449$.

12. Varella IS, Wagner MB, Darela AC, Nunes LM, Muller RW. Seroprevalence of toxoplasmosis in pregnant Women. J Pediatr 2003; 79:69-74.

13. Gollub EL, Leroy V, Gilbert R, Chene G, Wallon M, European Toxoprevention Study Group (EUROTOXO). Effectiveness of health education on Toxoplasmarelated knowledge, behavior, and risk of seroconversion in pregnancy. Eur J Obstet Gynecol Reprod Biol 2008; 136:137-145.

14. Lopez A, Dietz VJ, Wilson M, Navin TR, Jones JL, Division of Parasitic Diseases, National Center for Infectious Diseases. Preventing congenital toxoplasmosis. MMWR Recomm Rep 2000; 49:57-75.

15. Couto JCF, Avelino MM, Ferreira QT. Toxoplasmose e gestação. In: Couto JCF, Andrade GNQ, Tonelli E, editors. Infecções Perinatais. Rio de Janeiro: Guanabara Koogan; 2006. p. 471.

16. Remington JS, Thulliez P, Montoya JG. Minireview, Recent developments for diagnosis of toxoplasmosis. J Clin Microbiol 2004;42:941-945.

17. Montoya JG, Remington JS. Management of Toxoplasma gondii infection during pregnancy. Clin Infect Dis 2008;47:554-566.

18. Lago EG, Cunha-Neto E, Melamed J, Rucks AP, Presotto C, Coelho JC et al. Congenital toxoplasmosis: late pregnancy infections detected by neonatal screening and maternal serological testing at delivery. Paediatr Perinat Epidemiol $2007 ; 21: 525-531$.

19. Bessieres MH, Berrebi A, Cassaing S, Fillaux J, Cambus JP, Berry A, et al. Diagnosi of congenital toxoplasmosis: prenatal and neonatal evaluation of methods used in Toulouse University Hospital and incidence of congenital toxoplasmosis. Mem Inst Oswaldo Cruz 2009; 104:389-392.

20. McLeod R, Boyer K, Karrison T, Kasza K, Swisher C, Roizen N, et al. For The Toxoplasmosis Study Group. Outcome of Treatment for Congenital Toxoplasmosis, 1981-2004: The National Collaborative Chicago-Based, Congenital Toxoplasmosis Study. Clin Infect Dis 2006; 42:1383-1394.

21. Gras L, Gilbert RE, Ades AE, Dunn DT. Effect of prenatal treatment on the risk of intracranial and ocular lesions in children with congenital toxoplasmosis. Int J Epidemiol 2001; 30:1309-1313.

22. Wallon M, Liou C, Garner P, Peyron F. Congenital toxoplasmosis: systematic review of evidence of efficacy of treatment in pregnancy. BMJ 1999; 318:1511-1514.

23. Pinon JM, Dumon H, Chemla C, FranckJ, Petersen E, Lebech M, et al. Strategy for diagnosis of congenital toxoplasmosis: evaluation of methods comparing mothers and newborns and standard methods for postnatal detection of immunoglobulin G, M, and A antibodies. J Clin Microbiol 2001; 39:2267-2271.

24. Andrade GMQ Tonelli E, Oréfice F. Toxoplasmose e gestação. In: Couto JCF Andrade GNQ, Tonelli E, editors. Infecções Perinatais. Rio de Janeiro: Guanabara Koogan; 2006. p. 471-492.

25. Sáfadi MAP, Berezin EN, Farhat CK, Carvalho ES. Clinical presentation and follow up of children with congenital toxoplasmosis in Brazil. Brazilian J Infect Dis 2003; 325-331.

26. Wallon M, Kodjikian L, Binquet C, Gargweg J, Fleury J, Quantim C et al. Longterm ocular prognosis in 327 children with congenital toxoplasmosis. Pediatrics 2004; 113:1567-1572. 